\title{
THE HALL-MILLS MURDER CASE: THE MOST FASCINATING UNSOLVED HOMICIDE IN AMERICA
}

\author{
$B Y$ MARY S. HARTMAN
}

Dr. Hartman is Dean of Douglass College, Rutgers University

The jacket blurb on William Kunstler's recently reissued book
on the Hall-Mills case dubs it "the most fascinating unsolved
homicide in the annals of American crime." For once, such promotional hype is not hyperbole, although I admit to some prejudice in this view which I will explain in a moment. There was national, even international sensation in September 1 922, when the bodies of an Episcopalian rector and of a choir singer from his church in New Brunswick were discovered under a crab apple tree off a well-known lovers' lane just outside town. The pair had been missing for two nights and a day when a young working-class couple stumbled across the grisly tableau which had been staged by the murderer or murderers.

Edward Wheeler Hall and Eleanor Reinhardt Mills lay on their backs, side by side, she with a scarf draped over her neck and her head resting on the minister's outstretched arm, he with his glasses resting on his nose and his face partly covered by a Panama hat. Effusive and incriminating love letters from Mrs. Mills to the Reverend Mr. Hall were strewn about the bodies; and the minister's calling card with his name printed in gothic letters was carefully propped up against his lifeless foot. The forty-one-year-old minister had been shot once in the head; and the thirty-four-year-old soprano had three bullets in her skull. The woman's throat, moreover, had been slashed with such violence that the head was nearly severed. To this day, local residents still regale newcomers to New Brunswick with rumors that the victims' bodies were also sexually mutilated; there is no credible supporting evidence for such claims.

' William M. Kunstler, The Hall-Mills Murder Case: The Minister and the Choir Singer (New Brunswick: Rutgers University Press, I980). The study was originally published in 1964. There is one other book-length study of the case, written by Charles Boswell and Lewis Thompson, published in 1953 entitled The Girl in Lover's Lane. 
(The autopsy report, at least, noted that Hall's genitalia were "normal.") More striking was the discovery first made by a doctor conducting an autopsy four years later in 1926 on the exhumed body of Eleanor Mills: the tongue and vocal chords of the choir singer had been cut out and removed.

We may never know who performed these deeds; but even without the satisfaction of that certainty, there is something for everyone in the records of this astonishing case, a number of which are in the Special Collections of Rutgers University's Alexander Library. For the student of the lives of women, these records are rich, for like so many criminal proceedings, they are windows on the daily habits, reactions and routines of a group normally hidden from history. From the proud Frances Hall, whose aristocratic privacy was forever blasted, to the eccentric farmer and raiser of livestock, Jane Gibson, quickly labelled the "pig woman," whose accusations helped bring the widow and her two brothers finally to trial in I 926, to the flamboyant Charlotte Mills, who protested the dilatory efforts to find her mother's killer while proclaiming herself a "flapper" to the press, to the scores of indignant New Brunswick matrons who announced their "firm belief in Mrs. Hall's absolute innocence" in a petition published in the local Home Neros, to the pathetic victim herself, whose awkward declarations of love, penned in happier days in a schoolgirl's hand, were destined to be read aloud by a nervous court clerk for the world to hear, the Hall-Mills case is one which belongs peculiarly to women. "I know there are girls with more shapely bodies, but I do not care what they have," Eleanor Mills had declared in one of these letters, which the police had duly gathered up from the scene of the crime. "I have the greatest of all blessings, a noble man, deep, true, and eternal love. My heart is his, my life is his, all I have is his, poor as my body is, scrawny as they say my skin may be, but I am his forever."

The suggestion that the testimony and other records of criminal trials offer a wealth of materials for social historians, and especially for historians of women, is not a new one. Ann Jones in Women Who Kill (New York: Fawcett Columbine Books, I 980) surveyed America's female murderers from colonial times to the present; and I may have contributed something to an interest in trial sources for 
women's history through my Victorian Murderesses (New York: Schocken, 1977). But my admitted prejudice in concurring with the judgment that the Hall-Mills case is America's most fascinating unsolved homicide involves more than mere academic interest, if an interest in murder can ever be so described. In my own case, the fascination with the crime comes closer to home. Literally. As the present Dean of Douglass College, the women's college of Rutgers University, I live in the famous mansion on Nichol Avenue from which the rector of St. John's Church set out never to return on the evening of September I4, I 922. He left behind his wife Frances, his odd resident brother-in-law Willie Stevens, a maid named Louise Geist, and his ten-year-old niece Frances Voorhees, who was visiting from Jersey City. Long after Frances Hall and her brothers were acquitted of the killings which took place later that evening a few miles away, she and Willie lived on in the threestory mansion, then on a full city block, which was billed as one of the grandest residences in town and which had been their childhood home. Soon after Mrs. Hall died in 1942, the house was purchased by the women's college, and it has been the home of the dean of the college ever since.

Settling into 23 Nichol Avenue as the author of a book on murder, and one who as a Douglass faculty member had given the occasional local lecture on the Hall-Mills case, has had its bizarre moments. True, days and even weeks can go by with nary a thought to the comings and goings on that night in 1922 when the college's watchman reported that contrary to custom, lights blazed in the Hall home until 2:30 a.m. But sooner or later a guest will inquire whether the house is haunted, or the doorbell will ring and a stranger who has been reading about the case will ask politely for a look around. It is a bit like being on a perpetual, somewhat macabre, busman's holiday. But back to the case and, in due course, to the collections devoted to it in the University's archives.

Edward Wheeler Hall and Frances Stevens Hall were already well-known New Brunswick residents by 1922, though for somewhat different reasons. Edward had been born to comfortable but not wealthy middle-class parents in Brooklyn in I $88 \mathrm{I}$. He took a degree in Liberal Arts from the Brooklyn Polytechnic Institute and attended General Theological Seminary in Manhattan; and he had served in churches in New York and in Basking Ridge, New Jersey, 
before he was installed in I 909 at St. John's, New Brunswick. There, after briefly courting a parishioner of rather limited means, the handsome rector turned his attentions to Frances Stevens, the only daughter of one of the town's most prominent families, who taught in the St. John's Sunday School. Frances was seven years older than Edward; and when the pair married in I9I I she was thirty-seven and he was thirty. (The closest a reporter ever came later to a compliment on her physical appearance was the admission that Mrs. Hall was "not wholly unattractive.") Some assumed at the time of their marriage that the groom had his eye on money and status, and perhaps it was so. Through their mother and aunt, Frances Stevens and her two brothers, heirs of the Johnson surgical supply fortune, reportedly shared almost two million dollars. The newlyweds immediately moved into the bride's family home; and Edward assumed the responsibility of monitoring the weekly allowance for Frances' older brother Willie, who was not employed and who spent much of his time down at the New Brunswick firehouse. It was not a terribly exciting domestic life, at least at the beginning. Church activities were all. The minister normally breakfasted with his wife, worked in his study in the morning, and made calls in the afternoon. After supper at 6:30 there were more evening calls, or perhaps meetings at the church.

Five blocks from the Halls on Carman Street in a rundown frame house lived James and Eleanor Mills-he an ex-shoemaker turned church sexton, she a soprano in the choir since fourteen, married at fifteen, mother of two children and a pillar of the Ladies' Auxiliary of the church. James Mills never made more than thirtyeight dollars a week in his life, and Eleanor Mills apparently found solace in romantic novels and church activities. She went to St. John's almost every day. Just when the affair with the Reverend Mr. Hall began is uncertain; but by the end of I9I9, he was already calling on the Mills almost every day. Mr. Mills told a reporter shortly after the murders that Edward Hall was his best friend. Mills seems to have been something of a simpleton, though he obviously knew more than he appeared to. In this way, he and Willie, Mrs. Hall's brother, were much alike. Mills may have been willing to take advantage of the money Hall spread about, and so to put up with his wife's affair. In any case, he had a moderately good alibi for the murder night. Mrs. Hall, too, said 
she had been at home that night, and a maid's word backed her up. (Later the maid's word was to be challenged.) Mrs. Hall, like Mr. Mills, claimed to know nothing about the love affair of her spouse; but it seems clear that she too knew a great deal. Certainly most of the parishioners at St. John's, and a good many others in town, were aware of the relationship. On the morning after the murders, Mrs. Hall told Mills that her husband had been gone all night, and the sexton replied that his wife had been gone too. He added, "Do you suppose they have eloped?" The reported remark would cause him considerable embarrassment later.

The first obstacle to discovering what happened was the fortuitous fact of a county line. Both the Millses and the Halls lived in Middlesex County; but the bodies were found near the notorious lovers' lane, which was in Somerset County. Both county prosecutors then got into the act, as both New Brunswick and Somerville police had done earlier. Moreover, almost as soon as the authorities at the police station in New Brunswick learned about the murders on Saturday morning, September I6, the newspaper reporters and a number of private citizens made their way to the site, where they trampled the ground and began to strip the bark of the crab apple tree for souvenirs.

Soon after the funerals early the following week, judges in both Middlesex and Somerset counties urged the grand juries to begin hearings on the case, and the two county prosecutors rivaled one another in interviewing people and turning up stories. After two weeks passed with no leads, the Governor, who had been feeling pressure to solve the crime, said he had urged the two county prosecutors to cooperate with one another. They did, and one of their first acts in early October was to go to 23 Nichol and take Willie away for questioning without even permitting him to tell his sister where he was going. Mrs. Hall in the meantime had hired her own lawyer to investigate her husband's death, and the lawyer asked whether Mrs. Hall could expect the same treatment. Gallantry prevailed, and the prosecutor maintained that they certainly would not treat a woman that way. Mrs. Hall had only been questioned once, and gently, two days after the discovery of her husband's body.

Meanwhile others were being questioned, and not so gently: in particular, the fifteen-year-old factory worker Pearl Bahmer and 
her sometime twenty-two-year-old boyfriend who had found the bodies. The boyfriend, Raymond Schneider, stated that on the night of the murders a second young man had been with him and that they had followed his girlfriend and her father, who were walking together in the neighborhood of the killing. The boyfriend maintained that his companion, who had also dated the girl, suspected that the father was guilty of incest and intended to do away with him. He swore that this young man, called Clifford Hayes, had killed Edward Hall and Eleanor Mills in a case of mistaken identity. Amazingly, Hayes was arrested and charged on October 9. Of course the story did not explain the love letters, or the cut throat, or a multitude of other things; but clearly the need for an instant suspect was great, given the pressure from the state and the press. Then too, the suspect conveniently came from the right class, while Mrs. Hall and her brother were highly respected citizens. James Mills was grudgingly left alone for the time being since neighbors had seen him within an hour of the alleged killings and had heard him doing woodwork, pounding nails, throughout the whole period in question. Soon, it was clear that only the Somerset prosecutor had wanted an arrest; and Middlesex citizens protested that it was no accident that wealthy folks from Somerset should want to pin the crime on a New Brunswick lad. Hundreds from town called at the boy's home to express sympathy, and a justice fund was created to pay for Hayes' defense. Many of these people knew that Schneider was an inveterate liar. And sure enough, a couple days later the young man confessed to the lie and Hayes was released. The prosecutors were again empty-handed.

Vendors meanwhile hawked balloons and soft drinks near the murder site every day as hundreds came to visit. Analysis of blood in the soil at the spot the bodies were found did suggest that the murders had in fact taken place there, so that the Somerset prosecutor was indeed the correct one. By that time, however, Mills had sold a diary of Hall's and some of his letters, which had been in his wife's possession, to a New York paper. A State Supreme Court judge, unhappy with the bungled investigation, turned it over in late October to the State Attorney General's office.

Unlike the Somerset prosecutor, the newly appointed special prosecutor took seriously the testimony of an eccentric woman who had come forward in mid-October after the Hayes accusation to 
say that she had been an eyewitness to the crimes and could not let an innocent person suffer. She contended that Mrs. Hall, her two brothers Willie and Henry, and a cousin named Henry Carpender, were all on the scene the night of the murder. This woman, Mrs. Jane Gibson (or Easton), declared she had heard and seen the murders as she lay in wait outside near her fields, hoping to catch whoever had been lately stealing her corn. Jane Gibson was admittedly a peculiar individual, and her account, which featured her mule Jenny, changed with each retelling. But there was enough other testimony by then which raised doubts about the whereabouts of Mrs. Hall, her brothers and the cousin to lend some credibility to the story of the "pig woman." Still, the Somerset grand jury, which met in late November for five days and heard sixty-seven witnesses, decided in the end not to indict. The case was dead, or so it seemed.

Nearly four years later, however, the affair was brought back to life when the husband of Louise Geist, one of the former maids in the Hall family, filed a petition for annulment of his marriage on the grounds that his wife had withheld knowledge of the HallMills case. He claimed in the petition that his wife had told Mrs. Hall on September I 4, I 922, the day of the murder, that she knew Hall intended to elope with Mrs. Mills. He also alleged that along with Mrs. Hall and Willie, his wife had been driven out to the lovers' lane that evening and intercepted the minister and the choir singer, that she had received five thousand dollars for "her part in the matter and for keeping quiet about it." 3 The newspapers, especially Hearst's Daily Mirror in New York, went to town on the new evidence, which Geist's husband obligingly supplied. The new Somerset prosecutor, stung into action, arrested Mrs. Hall in the middle of the night, as well as her two brothers and cousin. She alone would be released on bail until trial, after the State Senator from Hudson County, Alexander Simpson, was named special prosecutor with the intervention of Governor A. Harry Moore. Now, it appeared that the national press attention had renewed the resolve to find out whether Frances Stevens Hall and her relatives had any involvement in the crimes.

In the four intervening years, however, masses of evidence had vanished, including autopsy reports and grand jury testimony. It

${ }^{3}$ Kunstler, p. I I 5 . 
began to look as though the previous Somerset prosecutor, who had been so eager to pin the murder on a poor young worker, had systematically "mislaid" vital evidence. His brother, a druggist, turned out to have the grand jury testimony in his personal possession and was caught trying to sell it anonymously to a newspaper.

As new statements and documentation were being collected in the late summer of I 926, Mrs. Hall invited the press to her home. Her hair had turned completely white in the four years, but her manner was utterly at ease. She complained to reporters about being made an ogre by the press: "The trouble is, I am more or less an ordinary person, and that is not sufficiently picturesque. However, I am not going to cry about it. I'll make the best of it I can." 4

This time the Somerset grand jury, prompted both by the national attention and by some new testimony, indicted all four who had been charged in September, although in the end the State's prosecutor succeeded in a motion to try separately the cousin, Henry Carpender, against whom witnesses' testimony was least substantial. The trial itself lasted a month, beginning November 3. The State's prosecutor opened by naming Mrs. Hall as responsible for wanting to catch her husband and Mrs. Mills in flagrante delicto, and asking her two brothers to join her. The prosecutor pointed out that the calling card at the minister's foot was found to have Willie's thumb print on it, and that witnesses would testify that Mrs. Hall hired private detectives who had bribed key witnesses against her.

Witnesses for the prosecution included St. John's vestryman Ralph Gorsline, assistant manager for one of the companies owned by the Johnson family, who admitted what he had denied in 1922 , namely that he was present in the lovers' lane with a young woman from St. John's (not, he was distressed to admit, his wife) and that he had heard the shots at about IO: I 5 p.m. A former private detective from New York also identified Gorsline as the terrified man who had visited his office a few weeks after the crime. Gorsline, he said, acknowledged that conscience troubled him, since he had not only heard the shots but had had an encounter on the site with Henry Stevens, Mrs. Hall's brother, who had told him to get out and later had taken him to a lodge room and made him swear he would never tell what he had seen. Although Gorsline continued to deny the detective's statement, others identified him as part of an informal

4 Kunstler, p. 156. 
network of spies which included Minnie Clark, a Sunday School teacher from the church, who had kept Mrs. Hall informed in the summer of 1922 about meetings of her husband and the choir singer and also had intercepted some of the letters Eleanor Mills regularly left for her lover in a book in his study. Another witness testified that she saw Henry Stevens in New Brunswick the day after the crimes, when he insisted he was still at his home in Lavalette, New Jersey. Several others stated that a private detective hired by Mrs. Hall had attempted to bribe them to stay quiet. In addition, a hearse driver testified that on the day of Hall's funeral, although the widow wore a heavy veil, he had glimpsed her face briefly and observed that there were long, fresh scratches on her left cheek. Other prosecution witnesses stated that Willie Stevens had told them on the day after the murders (but the day before the bodies were discovered), that something "terrible" had happened.

Still, the State's case was weakened, in part because a number of its witnesses either were, or appeared, sleazy and unreliable. Their star witness Jane Gibson, who was hospitalized at the time of the trial, made a dramatic appearance when she was brought in on a stretcher; and her testimony was backed up in many details by other witnesses who saw her that evening and also saw the cars she mentioned near the lovers' lane. But the defense succeeded in blasting her testimony with standard courtroom sexual politics. They began to question her about her marital status and her previous husbands; and the woman's vague, evasive replies were sufficient to persuade the jury that nothing she said needed to be believed. One juror admitted afterwards that he would stay there thirty years rather than to convict anyone on the evidence the pig woman gave.

Frances Hall, by contrast, was presented as a paragon, along with her two brothers. "Have they been thugs?" her lawyer asked in summing up. "Have they criminal records, are they thieves? No, they are refined, genteel, law-abiding people, the very highest type of character, churchgoing Christians, who up to this time enjoyed the perfect admiration and respect of their friends and neighbors." 5 The defense, in fact, suggested not so subtly that either Mills or the pig woman herself were more plausible suspects. Frances Hall and her two brothers were acquitted. 
In a study of the case in I962, the lawyer William Kunstler argued that the jury at least reached the correct verdict. In his view, the $\mathrm{Ku}$ Klux Klan was responsible. Kunstler points out that the Klan, refounded in I 9 I 5 from the original Civil War group, was strongly committed to strict standards of sexual morality and known to punish severely anyone violating marital fidelity. Yet although he demonstrates the Klan's new strength in Jersey, Kunstler cannot tie the case directly in any way and admits his evidence is circumstantial. Moreover, all other instances he cites of vigilante retribution fall short of murder; tar and feathering, beatings, and the like were common in adultery cases, not murder.

Kunstler's was not the last word, and perhaps there will never be one. But there was something new, evidence which shows how jury trials are at the mercy of the factfinders. For there was some evidence which never came to light until I 970 , when a retired gas station owner who thought he was about to die ended an almost forty-eight year silence when he confided what he knew about the case to a patrolman and then to the New Brunswick Home Nerws. This man, Julius Bolyog, a seventy-year-old Hungarian, explained that he had played an unwitting role in the double murders as a deliveryman for Mrs. Hall herself, who transmitted six thousand dollars through him to two small-time New Brunswick hoodlums. (Bolyog, by the way, passed two polygraph tests.) Bolyog reported that he and Willie Stevens were old friends, which was entirely credible since Willie spent many hours with residents of the town's Hungarian community around Somerset Street. Willie had often told his friend how unhappy he was with his brother-in-law who, with his sister's approval, controlled his inheritance through a trust fund and gave him twenty-five dollars or so a week, not nearly enough to suit him, especially as he was friendly with a widow in town whom he hoped to marry. According to Bolyog, Willie also confided that his sister knew of the affair, and wanted to give her husband money to go away. Willie said he hoped to "take care of the bum," meaning his brother-in-law; but Bolyog refused, or so he said, to introduce him to some local thugs who specialized in such jobs. About six months later, the day after the murders when Hall was still missing (and Frances had informed the organist at the Church that her husband would not attend choir practice because he was "out of town"), Willie found Bolyog and told him he 
urgently needed his help. According to Bolyog, Willie led him down to George Street where his sister was waiting in a parked car with a man at the wheel. Willie asked him to take envelopes from Frances and give them to two young men standing in an alleyway, which he did. Willie told his friend that the pair had been forced into a car, murdered, and then brought to the lovers' lane; but later testimony and forensic evidence proved that each had got there under their own steam, and that the murders were committed on the spot. If Bolyog was telling the truth, Willie was either lying or had been lied to.

There is no wonderful murder mystery ending which pulls together all the loose ends, although a tantalizing statement taken in I 922 deserves mention. A minister friend of Hall's called Paul Hamborszky, who served the Hungarian community in New Brunswick and once travelled with Hall to a ministers' conference, told a newspaper at the time of the crime that Hall had confided to him that his wife knew all about the affair with the choir singer, and that one of her relatives had threatened to kill him unless he stopped seeing her. Hall, he said, told him that he had no intention of giving her up, that he was going to run away with Mrs. Mills very soon. Hamborszky had quoted Hall on the subject of his wife. "Mrs. Hall is a very cool woman. She has changed very much lately, and I am very much afraid that she will do me bodily harm."6 Was Hamborszky lying? We'll never know. He vanished on the eve of the trial in 1926 .

After the trial, the depositions and grand jury transcripts from I 922 and I926, as well as many other documents and physical evidence, remained in the prosecutor's office in Somerville where the case was tried. A subsequent Somerset prosecutor who had long been interested in the crime, Arthur Sutphen Meredith, built a display case for some of this evidence; but a number of years after he left that post for a judgeship in I 965 , a successor notified him that he was about to dispose of all the Hall-Mills material. Meredith then agreed to take possession; and in $198 \mathrm{I}$, just after the Rutgers Press reissued Kunstler's' book, Judge Meredith gave the HallMills' evidence to the Alexander Library at Rutgers.

The current collection does not include all the materials Kunstler

${ }^{6}$ Kunstler, p. 92. 
had consulted in 1962 when an inventory was made. Unfortunately, the depositions and grand jury testimony from 1922 and 1926 are no longer there. However, there are original newspapers and photographs, police correspondence, many letters from Frances Hall to Henry Stevens written between 1922 and 1926 , letters to and from the prosecutor's office, letters from Edward Hall to Mrs. Mills and from Mrs. Mills to Hall, diary transcripts from Hall written for his lover, and physical evidence, including clothing and personal effects of the victims, fingerprints, and a ghoulish plaster cast of Mrs. Mills' head used in the trial to describe her wounds. In addition, there are some University materials relevant to the case, in particular an issue of the college humor mazagine, the Chanticleer, which was banned by the Rutgers President in December I 926 when the New Brunswick City Council objected to its satirical treatment of the trial. The issue contained several cartoons, including one of the pig woman's mule and another of a sign announcing "Welcome to New Brunswick, the town that made Somerville Famous." The cartoons themselves are rather crudely executed, but their creator went on to become a famous son of Rutgers: He was Ozzie Nelson.

By now, all the principals in this celebrated affair are long dead. There is no telling whether the truth of the identity of the murderer or murderers will ever be uncovered, but the documents themselves have many other truths to tell about forgotten lives in our past. Here, surely, is America's most fascinating unsolved homicide. 